\title{
Social entrepreneurial intention: A systematic literature review and outlook
}

\author{
Bui Ngoc Tuan Anh ${ }^{1 *}$, Pham Xuan Lan ${ }^{2}$, Van Thi Hong Loan ${ }^{1}$ \\ ${ }^{1}$ Ho Chi Minh City Open University, Vietnam \\ ${ }^{2}$ University of Economics Ho Chi Minh City, Vietnam \\ *Corresponding author: anh.bnt@ou.edu.vn
}

\begin{abstract}
ARTICLE INFO
ABSTRACT

DOI:10.46223/HCMCOUJS. econ.en.11.1.1399.2021

Received: January $11^{\text {th }}, 2021$

Revised: January $22^{\text {th }}, 2021$

Accepted: January $26^{\text {th }}, 2021$

Keywords:

social entrepreneurial

intention, social

entrepreneurship, systematic

literature review

Since 2017, social entrepreneurial intentions are a rapidly growing field of research. The research to explain the formation of intent to establish social enterprises be approached from many aspects, as well as based on different theoretical backgrounds. However, a large part of this study lacked systematization and classifications, and there seems to be a tendency to start anew with every study. Therefore, there should be an overview of current knowledge in this field. In this sense, this article does a literature review of social entrepreneurial intentions. A total of 51/138 articles related to social entrepreneurial intentions searched from the Scopus database, published between 2006 and 2020, were analyzed. The purpose and contribution of this paper are to provide a clearer picture of the research approaches in social startup intent research. Several research gaps are identified in each of these approaches, with implications for researchers interested in filling these theoretical gaps.
\end{abstract}

\section{Introduction}

Social entrepreneur and social enterprise have existed for centuries, but the term social entrepreneurship has been introduced in recent decades (Poon, 2011; Short, Moss, \& Lumpkin, 2009; Singh, 2016). Social entrepreneurship involves innovative approaches to solving problems in the areas of education, the environment, fair trade, health, and social equality and is seen as an important foundation for the sustainable development of nations (Mair \& Noboa, 2006). In the development process of countries, there are always gaps in solving social problems, while the efforts of governments, commercial enterprises, and nonprofits have failed to meet the expectations of many stakeholders. Therefore, business activities aimed at creating sustainable and fair values for society are seen as an agent of social wealth, and promoting social entrepreneurship becomes a phenomenon was noticed in both practice and academia worldwide (Alderson, 2012; Santos, 2012; Tiwari, Bhat, \& Tikoria, 2017b; Urban, 2008; Urbano, Toledano, \& Soriano, 2010).

From an academic point of view, starting a business is a multi-step process that leads to starting a business (Krueger, Reilly, \& Carsrud, 2000; Shane \& Venkataraman, 2000). In other words, any decision to start a new business is planned rather than a transient response (Krueger et al., 2000). As long as one owns a business intent, he or she is most likely to enter the entrepreneurial behavior (Ajzen, 1991; Krueger \& Carsrud, 1993). Therefore, the intention to start a business is an important factor in entrepreneurship research as well as in social entrepreneurship (Lee \& Wong, 2004; Tran \& Von Korflesch, 2016). 
The research intends to social entrepreneurial intentions as grown rapidly from a pioneer model of Mair and Noboa (2006) on the intention to start a social enterprise. Since then, other researchers have continued testing and expanding this model. Besides, theoretical frameworks that are very successful in the field of commercial entrepreneurship are applied and developed in the field of social entrepreneurship, viz the theory of planned behavior (Ajzen, 1991) and Shapero's startup events (Shapero \& Sokol, 1982).

However, most existing studies lack systematization and classification and are inclined to duplication of the previous studies. In the absence of systematic synthesis, studies are prone to stagnation and lack of certainty (Fayolle \& Liñán, 2014). In another aspect, the existing research focuses on understanding the role of these factors that directly and indirectly impact the social entrepreneurial intention. However, the classification of those factors is still quite limited. Therefore, the review of the literature is necessary for future studies to avoid the mentioned limitations. In particular, this will help determine not only the main topics in the existing theoretical system but also help to identify existing gaps. Another advantage is a research literature review helps synthesize knowledge and identify future research directions (Sutter, Bruton, \& Chen, 2019). All of the above challenges indicate the need to conduct a research overview of social entrepreneurial intention. This paper aims to answer the research question: "What do the factors influence social entrepreneurial intention?" as well as point out research gaps that need to be explored.

\section{Methods of research}

This study will be performed using a systematic literature review. This method will help identify and make it easier for researchers to review previous research papers. These steps for a systematic document review are followed by Tranfield, Denyer, and Smart (2003), making it easier for researchers to identify research topic coverage and implement exclusion procedures that are inconsistent with research recommendations. Using this methodology will help researchers to easily grasp the knowledge of the research field. The methodology of Tranfield et al. (2003), uses five steps: planning, searching, screening, extraction, and synthesis.

Step 1 (planning): Make a research plan by defining a research question. This study began with the question: "What factors influence social entrepreneurial intentions".

Step 2 (searching): Perform a search based on reliable databases through the keywords related to the research question. To ensure the quality of the overall research, the quality journals should be the basis to perform a search (Rowley \& Slack, 2004; Wallace \& Wray, 2011). Scopus, Google Scholar, Microsoft Academic databases are used for this purpose. In it, Google Scholar and Microsoft Academic were used to check the adequacy of the studies found in Scopus. Scopus is preferably selected for this study instead of Web of Science because of its several advantages. Scopus is equivalent to the Web of Science as both are the two most popular and reliable electronic science databases (Archambault, Campbell, Gingras, \& Larivière, 2009; Falagas, Pitsouni, Malietzis, \& Pappas, 2008). Furthermore, Scopus covers a wider journal range, which is useful for both keyword search and citation analysis compared to Web of Science (Falagas et al., 2008). The phrases "social", "entrepre*" and "intent*" were searched in the databases mentioned above. Time to search for studies before December 20, 2020. The research results have found Scopus (138 items), Google Scholar (145 items), Microsoft Academic (206 items).

Step 3 (screening): Screening for the study according to the objectives of the research question. Preliminary screening based on the information summary of the article, according to the following basic criteria: only selected articles in English; just select the journal papers (books, 
book reviews, notes and articles from conferences has been eliminated) as recommended by (Jones, Coviello, \& Tang, 2011; Podsakoff, MacKenzie, Bachrach, \& Podsakoff, 2005); no duplication; articles present empirical research methods. The in-depth screening step is done based on the specific content of the article, the selection criteria are the article content must serve the initial research question of the review. This process eliminated 87/138 studies in Scopus results. As a final result, 51 articles were retained for content analysis.

Step 4 (extraction): Analysis of articles selected to answer the research question. Based on the results of the screening criteria above, we have obtained 51 articles from the results obtained to search "social entrepreneurial intention" as a general search technique. Next, based on the research questions, we seek to focus on themes for the social entrepreneurial intentions. Technical content analysis was used to analyze 51 articles because this technique is capable of identifying the key areas of research topics (Elo \& Kyngäs, 2008; Krippendorff, 2004). In the classification, any differences that affect the classification of things are evaluated and considered by group discussions with experts. The issue has been discussed and resolved by agreement. Some minor changes have been made to integrate these differences. Microsoft Excel is used in this case as a tool to manage the database. This is a very useful tool to be able to learn and analyze articles and structure evaluation as available columns in Excel (Tranfield et al., 2003). Using Excel columns, researchers can group information about aspects of the paper. The information that researchers do is by grouping the articles in the form of title, author, publisher, year of publication, background theory, the variables studied.

Step 5 (synthesis, including reporting): Research results. In this section, the researcher will explain the findings of a systematic assessment that have been identified based on group criteria in an Excel database.

\section{Results of study and discussion}

\subsection{Descriptive analyses}

Figure 1 shows the number of articles published annually from 2006 to 2020 . Although the concept of social entrepreneurial intention was first introduced by Mair and Noboa (2005) in their book, the growing interest in social entrepreneurial intention only started in 2010 with the article of Nga and Shamuganathan (2010). The number of articles has increased rapidly since 2017 , suggesting that this research topic is receiving increasing attention from the academic community.

Two articles that have influential generated mutations in this phase could include the Hockerts (2017) and Urban and Kujinga (2017b). It is worth noting that these two studies were directed towards the experimental model of forming the social entrepreneurial intention proposed by Mair and Noboa (2006). Also, Hockerts (2017) is interested in providing a reliable scale for use in the context of social entrepreneurial intention, tested in a sample of students from 32 different countries. 


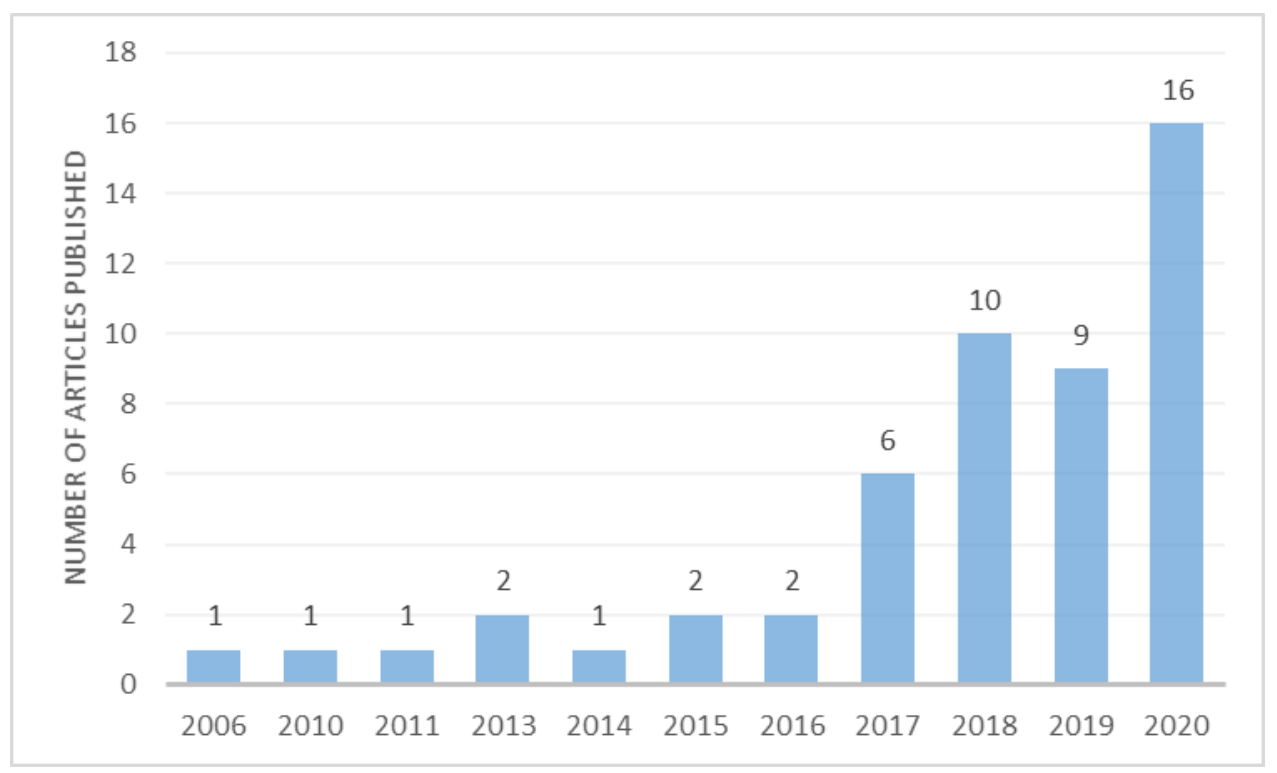

Figure 1. Number of articles published annually from 2006 to 2020*

(* Data collected until December 20, 2020)

Table 1 describes the geographic areas in which the empirical articles were collected. Asia is showing interest in this area through the number of publications and has been increasing in recent years, while other regions are relatively limited. The intention to start social entrepreneurship could also become an emerging topic in Africa and America, where social issues are becoming more diverse. The presence of unregulated areas is the reason the studies published only conceptual models, as well as 6 articles that were studies conducted on sample-based surveys in many different countries.

\section{Table 1}

Number of published articles by geographic area

\begin{tabular}{|c|c|c|c|c|c|}
\hline $\begin{array}{l}\text { Publishing } \\
\text { year }\end{array}$ & Asia & Europe & America & Africa & $\begin{array}{c}\text { Multinational research/ } \\
\text { Not mentioned }\end{array}$ \\
\hline 2006 & & & & & 1 \\
\hline 2010 & 1 & & & & \\
\hline 2011 & & & & & 1 \\
\hline 2013 & 1 & & & & 1 \\
\hline 2014 & & 1 & & & \\
\hline 2015 & & 1 & & & 1 \\
\hline 2016 & & 1 & & & 1 \\
\hline 2017 & 2 & & 1 & 2 & 1 \\
\hline 2018 & 4 & & 1 & 1 & 4 \\
\hline 2019 & 6 & 1 & 1 & & 1 \\
\hline 2020 & 10 & & 1 & 3 & 2 \\
\hline
\end{tabular}

Source: The researcher's data analysis

Figure 2 shows the statistics of articles published between 2006 and 2020 by country. 
Interestingly, Vietnam is among the top publishers of social entrepreneurial intentions, along with other countries such as South Africa, Malaysia, India, and China. Notably in this list, excluding China, the remaining 4 countries including Vietnam are all emerging economies according to the Morgan Stanley Capital International classification. This is quite reasonable when researchers agree that starting a social enterprise is considered a key factor for a country's sustainable development (Lacap, 2018; Mair \& Noboa, 2006). The development of the social enterprise is considered to be an opportunity for growth, especially in countries with emerging economies (Kabbaj, Hadi, Elamrani, \& Lemtaoui, 2016). In Figure 2, there are also 7 articles that do not mention the specific country in the study as well as 6 research papers conducted in cross-countries (6 articles).

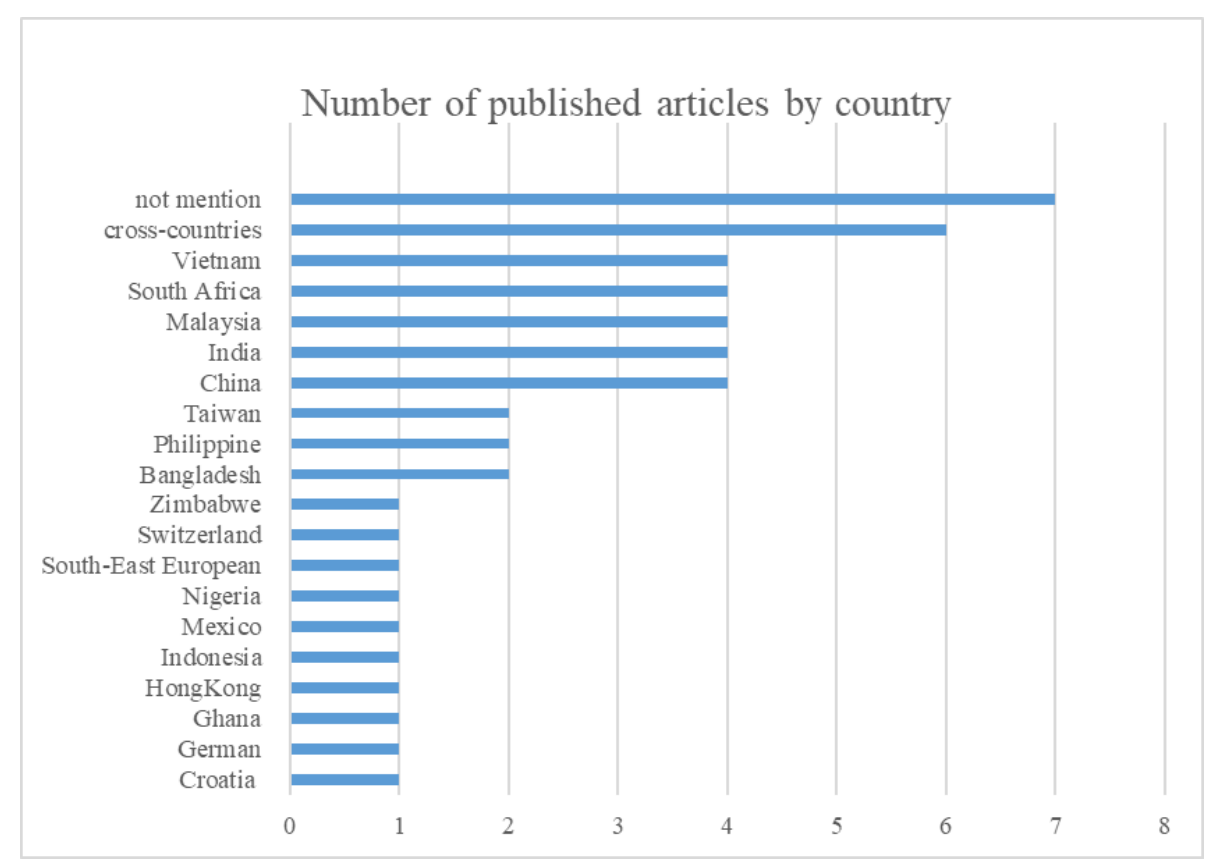

Figure 2. Number of published articles by country

Figure 3 depicts the economic sector mentioned in the study. It can be seen that the emerging economies have many empirical studies on social entrepreneurial intentions with articles 24/51 (47\%). Besides, with a lengthy history of research on social entrepreneurship, developed countries contributed 9 articles in this statistical results section.

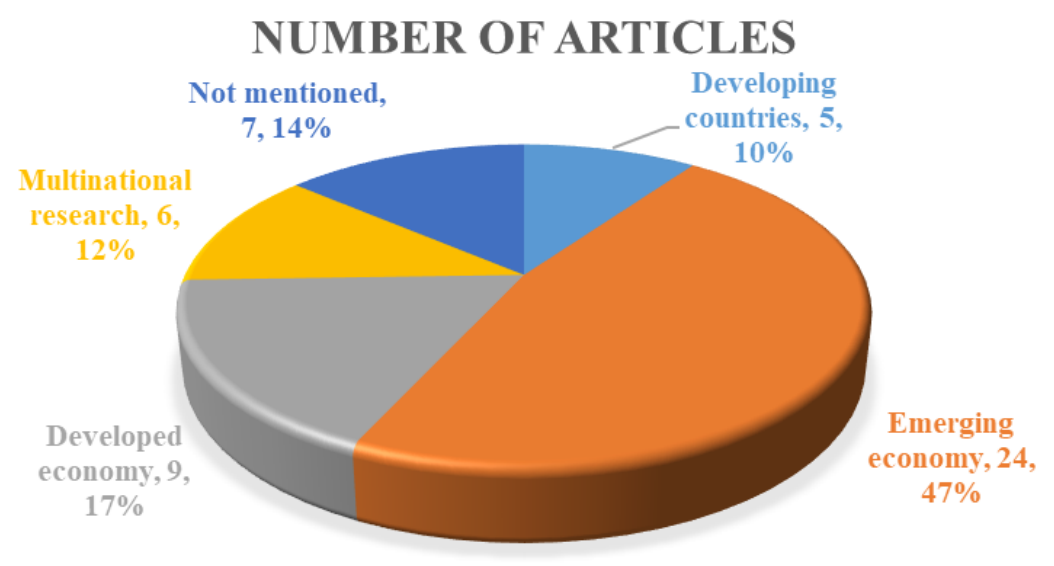

Figure 3. Distribution of studies by economic area 


\subsection{Thematic analyses}

Social Cognitive Theory (SCT) states that human behavior is influenced by personal factors, behavior, and interactive environment in a three-dimensional relationship (Bandura, 1986; Lent, Ireland, Penn, Morris, \& Sappington, 2017; Wood \& Bandura, 1989). While awareness of individuals contributing to the behavior of people, the environment also equally important for the career choices of people (Wood \& Bandura, 1989). This theoretical view is fully supported with the results of general analysis when leading to three topics: (1) testing and developing research models for social entrepreneurial intention; (2) the humanity of social entrepreneurs; (3) context factors.

\section{(1) The first approach is to test and develop research models of social entrepreneurial intention}

In this approach, the studies that attempt to test the original model or expand the social entrepreneurship intent model revolve around three background theory approaches. The first theory stems from social psychology, the most used is the theory of planned behavior (TPB) of Ajzen (1991). This theory aims to analyze behaviors in general and elucidate the process leading from beliefs, attitudes to effective actions. The TPB has always attracted a large amount of research and is still being applied in the area of intent to start a social enterprise (Barton, Schaefer, \& Canavati, 2018; Cavazos-Arroyo, Puente-Díaz, \& Agarwal, 2017; Ernst, 2011; Jemari et al., 2017; Lukman et al., 2020; Pham \& Phan, 2020; Phan, 2018, 2020; Politis, Ketikidis, Diamantidis, \& Lazuras, 2016; Prieto, 2011; Rivera, 2018; Tiwari, Bhat, \& Tikoria, 2017a; Tiwari et al., 2017b, Tiwari, Bhat, \& Tikoria, 2017c; Yang, Meyskens, Zheng, \& Hu, 2015).

The second theoretical direction, to characterize the field of entrepreneurship as the entrepreneurial potential model (EPM) of Krueger and Brazeal (1994) (Ayob, Yap, Sapuan, \& Rashid, 2013; Mair \& Noboa, 2005); model of entrepreneurial events (SEE) of Shapero and Sokol (1982). Notably, the SEE almost only empirically through models of Mair and Noboa (2006) and put this model to become one of the main models in the field of research social entrepreneurial intentions. Like the TPB, the research and development on the Mair and Noboa (2006)'s model also appeared frequently in the line of research on the intention to start a social enterprise (Ashraf, 2019; Aure, 2018; Baierl, Grichnik, Spörrle, \& Welpe, 2014; de Sousa-Filho, Matos, da Silva Trajano, \& de Souza Lessa, 2020; Forster \& Grichnik, 2013; Ghatak, Chatterjee, \& Bhowmick, 2020; Hockerts, 2013, 2017; Igwe et al., 2020; Ip, Liang, Wu, Law, \& Liu, 2018; Lacap, Mulyaningsih, \& Ramadani, 2018; Liu, Liang, Chang, Ip, \& Liang, 2020; Mair \& Noboa, 2006; Rambe, 2019; Urban \& Kujinga, 2017a,b).

Third, it is not impossible to mention Tran and Von Korflesch (2016) groundbreaking theoretical approach. They have contributed to the theoretical basis of social entrepreneurship by providing a new social entrepreneurial intentional model based on the social cognitive career theory (SCCT). This theory considers individuals choosing to become a social entrepreneur as well as choosing a social career and aims to explain their decision-making.

Occupying a remarkable number of studies on social entrepreneurial intentions, the TPB proves to have been and remains an appropriate theoretical foundation in this area of study (Zaremohzzabieh et al., 2019). Some researchers agree on this when noted that most of the recent research has focused on the expansion of TPB (Hockerts, 2017; Mair \& Noboa, 2006; Tran \& Von Korflesch, 2016). However, in the field of social entrepreneurship, research on the intent to start a social entrepreneur is in an early stage (Ernst, 2011). Ayob et al. (2013) and Prieto (2011) stated that intentions and their prefixes are still ambiguous and are being studied in the area of social entrepreneurial intentions. 


\section{(2) The second approach is to focus on the person of the social entrepreneur}

This approach dominates when the majority of social entrepreneurship studies to date is related to social entrepreneurs and their personalities (Light, 2011; Shaw \& Carter, 2007). Traits theory combined with motivational theory, the theory of intent is used to explain the relationship. Under this approach, the characteristics, different personalities of each individual will affect the intent behavior, so they can affect the intention to start a business (Espíritu-Olmos \& SastreCastillo, 2015). Regarding this approach, the researchers exploited factors such as (2.1) personality traits, (2.2) perception, (2.3) background factors (demographics, education, work experience work) in the formation of social entrepreneurial intentions.

(2.1) In the personality traits approach with the intention of starting a social business, studies can be classified in three main directions: human "general traits", "entrepreneurial traits" and "prosocial traits" (Stephan, 2017).

Features "general traits" is often described model revolves around five major personality traits (Big Five model) (Goldberg, 1990). McCrae and Costa (1987) has divided the personality into five personality popular and most commonly include extraversion (also often spelled extroversion), agreeableness, openness, conscientiousness, and neuroticism. These general traits show an association with the intention to start a social enterprise (Aure, 2018; Hsu \& Wang, 2019; Ip, Wu, Liu, \& Liang, 2018; İrengün \& Arıkboğa, 2015; Nga \& Shamuganathan, 2010; Preethi \& Priyadarshini, 2018). Overall, for the five major personality traits, the social entrepreneur does not show much difference from the commercial entrepreneur (Lukes \& Stephan, 2012).

In the direction of "entrepreneurial traits", studies suggest that social entrepreneurs are similar to commercial entrepreneurs, sharing similar personalities (Shaw \& Carter, 2007). The two types of entrepreneurs seem to exhibit similar risk-taking propensity, proactive personality, fear of failure, creativity, self-efficacy, and willingness to take responsibility (Bacq, Hartog, \& Hoogendoorn, 2016; Bargsted, Picon, Salazar, \& Rojas, 2013; Chipeta \& Surujlal, 2017; Kedmenec, Rebernik, \& Perić, 2015; Liu et al., 2020; Lukes \& Stephan, 2012; Politis et al., 2016; Prieto, 2011; Smith, Bell, \& Watts, 2014). Thus, the similarity between the two types of business when considering the entrepreneurial traits does not contribute much in promoting the number of social entrepreneurs.

With a third approach to "prosocial traits", researchers argue that social entrepreneurs have unique characteristics compared to commercial entrepreneurs (Austin, Stevenson, \& Wei-Skillern, 2006). This led to the discovery of the unique characteristics of social entrepreneurs, collectively known as prosocial personality (Penner, Dovidio, Piliavin, \& Schroeder, 2005). Social character is related to helping, social responsibility, and empathy (Eisenberg, 2006). In the field of social entrepreneurship, social personalities have been discovered such as empathy, sympathy, and compassion, moral obligation is proven to create motivation of individuals to pursue starting up the social business. Social entrepreneurship (Bacq \& Alt, 2018; Bargsted et al., 2013; McMullen \& Bergman, 2017; Miller, 2012; Nga \& Shamuganathan, 2010; Waddock \& Steckler, 2016). With the elements of prosocial traits discovered, it may be reasonable to assume that someone with a degree of empathy or ethical prowess would choose to become a social entrepreneur after exposure to a specific social problem. However, it is Mair and Noboa (2006) that not everyone who empowers and ethically evaluates to become a social entrepreneur, these factors are only necessary but not enough conditions in the process of forming into the social entrepreneurial intentions. Souitaris, Zerbinati, and Al-Laham (2007) suggest further consideration because there is still something more than an individual's background, personality, or perceptions. Souitaris et al. (2007) continued to question whether the individual "falls in love" with a social business career 
and/or with a business opportunity driven by emotions and personal preferences rather than fair judgment by reason (Souitaris et al., 2007).

\section{(2.2) Cognitive approach}

Field study's perception in the process began to be noticed while providing a variety of mechanisms, both theory-based and empirically to understand how entrepreneurs approach their environment (Wilson, Kickul, \& Marlino, 2007). The difference in perceptions can be attributed to differences in entrepreneur aspirations, efficiency levels, motivation, and ability to absorb and use their educational background to acquire new knowledge (Unger, Rauch, Frese, \& Rosenbusch, 2011). In the field of social entrepreneurship, cognitive factors have been explored including perceived desirability, perceived feasibility, social support (Mair \& Martí, 2006), hardship in life and moral judgment competence (Kedmenec et al., 2015), human capital and social capital (Jemari et al., 2017), cognitive style (Tiwari et al., 2017c), perceived access to finance (Phan, 2018). Surprisingly, even though cognitive factors are exploited, individual differences are the highest predictor of action effectiveness - cognitive capacity is not getting research attention in the field of social entrepreneurship.

\section{(2.3) Approach upon the fundamental factors}

Except for personality traits, the social entrepreneurial intentions is also related to socialdemographic characteristics such as gender (Lortie, Castrogiovanni, \& Cox, 2017; Notais \& Tixier, 2017), the role of education (Hockerts, 2018; Shahverdi, Ismail, \& Qureshi, 2018). Also, some underlying factors such as different status (student and alumni) and types of universities (Radin, 2017), previous experience (Lacap et al., 2018). Gender (Estrin, Mickiewicz, \& Stephan, 2013), work experience, and education (Shumate, Atouba, Cooper, \& Pilny, 2014) are three of the most frequently mentioned variables that have been shown to influence the intention to initiate starting a social venture. Social entrepreneurship also seems to appeal to those who are not typical commercial entrepreneurs, especially women and those with higher education (Estrin et al., 2013). Shumate et al. (2014) find that two paths are leading to starting a social enterprise: the path of social activity and the path from a business. Earlier, Leadbeater (1997) explained that the origins of social entrepreneurship can come from three main sources: "Public sector", "private sector" and "voluntary sector". These findings point to a research gap from a demographic outlook when previous studies in the field of social entrepreneurship have focused primarily on students (Ernst, 2011; Hockerts, 2017; Kirby \& Ibrahim, 2011; Nga \& Shamuganathan, 2010; Politis et al., 2016; Tiwari et al., 2017a,b).

\section{(3) The third approach: context factors}

Contextual factors are specific fundamental factors that include contextual barriers and the institutional environment support for business start-ups (Lüthje \& Franke, 2003). Situational variables include social, economic, and political factors, and how an individual perceives these factors may affect whether business intentions are being formed (Bird, 1988; Mair \& Noboa, 2006). The articles in this group focus on the influence of the regional, cultural, or institutional environment on the intent to start a social venture.

Several studies have compared samples from different countries to try to find contextual differences in participants' intentions to start a social business. Typically, some studies such as comparing the relationship between proactive personality and social entrepreneurial intention between African-American and Hispanic college students or not (Prieto, 2011); influenced by culture in China and the United States (Yang et al., 2015); a sample of international students from 32 different countries (Hockerts, 2017); between Taiwan and Hong Kong (Hsu \& Wang, 2019; Ip 
et al., 2018). Finally, the most recent article is more ambitious, as it compares three different countries: Bangladesh, India, Pakistan (Latif \& Ali, 2020).

Institutional support has also been shown to increase the relationship between attitudes and intention to start a social enterprise (Lukman et al., 2020), while the barrier from under-resourced is preoccupation (Shahverdi et al., 2018). In addition, organizational characteristics and social missions have a significant impact on the intention to start a social business (Tan \& Yoo, 2015).

Studies on social entrepreneurial intentions have been conducted in different countries and regions, typically Malaysia (Ayob et al., 2013; Nga \& Shamuganathan, 2010; Shahverdi et al., 2018), India (Tiwari et al., 2017b,c), Vietnam (Phan, 2018), South Africa (Chipeta \& Surujlal, 2017; Urban \& Kujinga, 2017b), Mexico (Cavazos-Arroyo et al., 2017), USA (Barton et al., 2018), Europe (Baierl et al., 2014; Hockerts, 2017; Politis et al., 2016). Regulatory institutions, norms, and cultural perceptions, directly and indirectly, influence the perceptions individuals may have of entrepreneurship desire and feasibility (Shane, 2008). Many authors have suggested that culture may influence the intention to start a social enterprise but empirical studies are lacking (Defourny \& Nyssens, 2010; Zahra, Newey, \& Li, 2014). Bacq and Janssen (2011) and Diochon and Ghore (2016) argue that understanding the influence of local contexts is very important in the social business sector.

\section{Conclusion}

As an emerging field and receiving a lot of practical and academic attention, research into the social entrepreneurial intention is increasing rapidly. However, when new knowledge appears, many questions need to be addressed. The paper makes an academic contribution to the classification of articles focusing on social entrepreneurial intention in the 2006-2020 period and identifies several gaps involved in each of these categories. By using a systematic literature review, this paper answers the research question "What's factors influence social entrepreneurial intention?". We collected various articles and included inclusion to answer the criteria of the research question. The results are 51 articles found from the Scopus database. The research results show that from 2017 to now there is an increase in the amount as well as the regions of publication.

The cross-country analyses have shown the ability to apply their broad model intended as TPB, SEE, but the researchers still have much work to do to fully understand how the different context of interacting with people in the identification of social entrepreneurial intention. The impact of countries' governing systems and legal policies on social entrepreneurship on intent also deserves further study (Engle et al., 2011). Evaluation can take place of public policy initiatives, incentives, and changes that aim to enable, encourage, and facilitate the social entrepreneurial intention. This approach can contribute to strengthening the link between social entrepreneurship research and public policy (Zahra \& Wright, 2011). Future studies need to focus on the specific contexts in the economic geographic research area. The comparative studies, investigating the specific factors in social entrepreneurial intentions in diverse contexts promises to provide more contributions to complete social entrepreneurship theory. Social entrepreneurs are characterized by altruism, so further research of social characteristics will also contribute to differentiating the essence of social and traditional entrepreneurs.

Although a rigorous methodology has been used for a systematic literature review, this study has certain limitations. First, a research question was developed for extracting article samples from a relevant online database. A set of keywords has been used for this purpose. Potential articles, however, may not be filtered as they may not have key search terms in their text. Furthermore, other relevant articles published in those journals (Web of Science) may have been 
omitted. Second, although the classification of the social entrepreneurial intention research topics is the result of a systematic step-by-step process, all of the extracted topics may not be mutually exclusive.

Although these studies have some limitations, we hope that this review will help researchers in the field of social entrepreneurial intention understand where this line of research is. We believe that this research result is also creating favorable conditions for scholars on social entrepreneurship.

\section{References}

Ajzen, I. (1991). The theory of planned behavior. Organizational Behavior and Human Decision Processes, 50, 179-211.

Alderson, K. J. (2012). At the crossroads: Social and faith-based entrepreneurship. Thunderbird International Business Review, 54(1), 111-116.

Archambault, É., Campbell, D., Gingras, Y., \& Larivière, V. (2009). Comparing bibliometric statistics obtained from the Web of Science and Scopus. Journal of the American Society for Information Science and Technology, 60(7), 1320-1326.

Ashraf, M. (2019). "Is old gold?" the role of prior experience in exploring the determinants of Islamic social entrepreneurial intentions: Evidence from Bangladesh. Journal of Social Entrepreneurship. doi:10.1080/19420676.2019.1702580

Aure, P. A. H. (2018). Exploring the social entrepreneurial intentions of senior high school and college students in a Philippine University: A PLS-SEM Approach. Journal of Legal, Ethical and Regulatory Issues, 21(2), 1-11.

Austin, J., Stevenson, H., \& Wei-Skillern, J. (2006). Social and commercial entrepreneurship: Same, different, or both? Entrepreneurship Theory and Practice, 30(1), 1-22. doi:10.1111/j.1540-6520.2006.00107.x

Ayob, N., Yap, C. S., Sapuan, D. A., \& Rashid, M. Z. A. (2013). Social entrepreneurial intention among business undergraduates: An emerging economy perspective. Gadjah Mada International Journal of Business, 15(3), 249-267. doi:10.22146/gamaijb.5470

Bacq, S., \& Alt, E. (2018). Feeling capable and valued: A prosocial perspective on the link between empathy and social entrepreneurial intentions. Journal of Business Venturing, 33(3), 333350. doi:10.1016/j.jbusvent.2018.01.004

Bacq, S., \& Janssen, F. (2011). The multiple faces of social entrepreneurship: A review of definitional issues based on geographical and thematic criteria. Entrepreneurship \& Regional Development, 23(5/6), 373-403. doi:10.1080/08985626.2011.577242

Bacq, S., Hartog, C., \& Hoogendoorn, B. (2016). Beyond the moral portrayal of social entrepreneurs: An empirical approach to who they are and what drives them. Journal Of Business Ethics, 133(4), 703-718. doi:10.1007/s10551-014-2446-7

Baierl, R., Grichnik, D., Spörrle, M., \& Welpe, I. M. (2014). Antecedents of social entrepreneurial intentions: The role of an individual's general social appraisal. Journal of Social Entrepreneurship, 5(2), 123-145. doi:10.1080/19420676.2013.871324

Bandura, A. (1986). The explanatory and predictive scope of self-efficacy theory. Journal of Social and Clinical Psychology, 4(3), 359-373. 
Bargsted, M., Picon, M., Salazar, A., \& Rojas, Y. (2013). Psychosocial characterization of social entrepreneurs: A comparative study. Journal of Social Entrepreneurship, 4(3), 331-346.

Barton, M., Schaefer, R., \& Canavati, S. (2018). To be or not to be a social entrepreneur: Motivational drivers amongst American business students. Entrepreneurial Business and Economics Review, 6(1), 9-35.

Bird, B. (1988). Implementing entrepreneurial ideas: The case for intention. Academy of Management Review, 13(3), 442-453.

Cavazos-Arroyo, J., Puente-Díaz, R., \& Agarwal, N. (2017). An examination of certain antecedents of social entrepreneurial intentions among Mexico residentes. Review of Business Management, 19(64), 180-218. doi:10.7819/rbgn.v19i64.3129

Chipeta, E. M., \& Surujlal, J. (2017). Influence of attitude, risk taking propensity and proactive personality on social entrepreneurship intentions. Polish Journal of Management Studies, 15(2), 27-36. doi:10.17512/pjms.2017.15.2.03

de Sousa-Filho, J. M., Matos, S., da Silva Trajano, S., \& de Souza Lessa, B. (2020). Determinants of social entrepreneurial intentions in a developing country context. Journal of Business Venturing Insights, 14, Article e00207.

Defourny, J., \& Nyssens, M. (2010). Conceptions of social enterprise and social entrepreneurship in Europe and the United States: Convergences and divergences. Journal of Social Entrepreneurship, 1(1), 32-53. doi:10.1080/19420670903442053

Diochon, M., \& Ghore, Y. (2016). Contextualizing a social enterprise opportunity process in an emerging market. Social Enterprise Journal, 12(2), 107-130.

Eisenberg, N. (2006). Empathy-related responding and prosocial behaviour. Novartis Foundation Symposium, 278, 71-80.

Elo, S., \& Kyngäs, H. (2008). The qualitative content analysis process. Journal of Advanced Nursing, 62(1), 107-115.

Engle, P. L., Fernald, L. C. H., Alderman, H., Behrman, J., O’Gara, C., Yousafzai, A., ... Ertem, I. (2011). Strategies for reducing inequalities and improving developmental outcomes for young children in low-income and middle-income countries. The Lancet, 378(9799), 1339-1353.

Ernst, K. (2011). Heart over mind - An empirical analysis of social entrepreneurial intention formation on the basis of the theory of planned behavior (Doctoral dissertation). Universität Wuppertal, Fakultät für Wirtschaftswissenschaft/Schumpeter School of Business and Economics, Wuppertal, Germany.

Espíritu-Olmos, R., \& Sastre-Castillo, M. A. (2015). Personality traits versus work values: Comparing psychological theories on entrepreneurial intention. Journal of Business Research, 68(7), 1595-1598.

Estrin, S., Mickiewicz, T., \& Stephan, U. (2013). Entrepreneurship, social capital, and institutions: Social and commercial entrepreneurship across nations. Entrepreneurship Theory and Practice, 37(3), 479-504. doi:10.1111/etap.12019

Falagas, M. E., Pitsouni, E. I., Malietzis, G. A., \& Pappas, G. (2008). Comparison of PubMed, Scopus, Web of Science, and Google Scholar: Strengths and weaknesses. The FASEB Journal, 22(2), 338-342. 
Fayolle, A., \& Liñán, F. (2014). The future of research on entrepreneurial intentions. Journal of Business Research, 67(5), 663-666.

Forster, F., \& Grichnik, D. (2013). Social entrepreneurial intention formation of corporate volunteers. Journal of Social Entrepreneurship, 4(2), 153-181.

Ghatak, A., Chatterjee, S., \& Bhowmick, B. (2020). Intention towards digital social entrepreneurship: An integrated model. Journal of Social Entrepreneurship, 10(12), 1-21. doi:10.1080/19420676.2020.1826563

Goldberg, L. R. (1990). An alternative "description of personality": The big-five factor structure. Journal of Personality and Social Psychology, 59(6), 1216-1229.

Hockerts, K. (2013). Antecedents of social entrepreneurial intentions: A validation study. In L. Toombs (Ed.), Academy of management proceedings 2013. Briarcliff Manor, NY: Academy of Management.

Hockerts, K. (2017). Determinants of social entrepreneurial intentions. Entrepreneurship Theory and Practice, 41(1), 105-130. doi:10.1111/etap.12171

Hockerts, K. (2018). The effect of experiential social entrepreneurship education on intention formation in students. Journal of Social Entrepreneurship, 9(3), 234-256. doi:10.1080/19420676.2018.1498377

Hsu, C.-Y., \& Wang, S.-M. (2019). Social entrepreneurial intentions and its influential factors: A comparison of students in Taiwan and Hong Kong. Innovations in Education and Teaching International, 56(3), 385-395. doi:10.1080/14703297.2018.1427611

Igwe, A., Ogbo, A., Agbaeze, E., Abugu, J., Ezenwakwelu, C., \& Okwo, H. (2020). Self-efficacy and subjective norms as moderators in the networking competence-social entrepreneurial intentions link. SAGE Open, 10(3), 1-16. doi:10.1177/2158244020934878

Ip, C. Y., Liang, C., Wu, S.-C., Law, K. M. Y., \& Liu, H.-C. (2018). Enhancing social entrepreneurial intentions through entrepreneurial creativity: A comparative study between Taiwan and Hong Kong. Creativity Research Journal, 30(2), 132-142. doi:10.1080/10400419.2018.1446744

Ip, C. Y., Wu, S.-C., Liu, H.-C., \& Liang, C. (2018). Social entrepreneurial intentions of students from Hong Kong. The Journal of Entrepreneurship, 27(1), 47-64. doi:10.1177/0971355717738596

İrengün, O., \& Arıkboğa, Ş. (2015). The effect of personality traits on social entrepreneurship intentions: A field research. Procedia-Social and Behavioral Sciences, 195(2015), 11861195. doi:10.1016/j.sbspro.2015.06.172

Jemari, M. A., Kasuma, J., Kamaruddin, H. M., Tama, H. A., Morshidi, I., \& Suria, K. (2017). Relationship between human capital and social capital towards social entrepreneurial intention among the public university students. International Journal of Advanced and Applied Sciences, 4(12), 179-184.

Jones, M. V, Coviello, N., \& Tang, Y. K. (2011). International entrepreneurship research (1989-2009): A domain ontology and thematic analysis. Journal of Business Venturing, 26(6), 632-659.

Kabbaj, M., Hadi, K. E. O. E., Elamrani, J., \& Lemtaoui, M. (2016). A study of the social entrepreneurship ecosystem: The case of Morocco. Journal of Developmental Entrepreneurship, 21(04), Article 1650021. 
Kedmenec, I., Rebernik, M., \& Perić, J. (2015). The impact of individual characteristics on intentions to pursue social entrepreneurship. Ekonomski Pregled, 66(2), 119-137.

Kirby, D. A., \& Ibrahim, N. (2011). The case for (social) entrepreneurship education in Egyptian universities. Education + Training, 53(5), 403-415. doi:10.1108/00400911111147712

Krippendorff, K. (2004). Reliability in content analysis: Some common misconceptions and recommendations. Human Communication Research, 30(3), 411-433.

Krueger, N. F., \& Brazeal, D. V. (1994). Entrepreneurial potential and potential entrepreneurs. Entrepreneurship Theory and Practice, 18(3), 91-104.

Krueger, N. F., \& Carsrud, A. L. (1993). Entrepreneurial intentions: Applying the theory of planned behaviour. Entrepreneurship \& Regional Development, 5(4), 315-330.

Krueger, N. F., Reilly, M. D., \& Carsrud, A. L. (2000). Competing models of entrepreneurial intentions. Journal of Business Venturing, 15(5/6), 411-432.

Lacap, J. P. G. (2018). Social entrepreneurial intentions of university students in Pampanga, Philippines. Journal of Entrepreneurship and Business, 6(1), 1-16. doi:10.17687/JEB.0601.01

Lacap, J. P. G., Mulyaningsih, H. D., \& Ramadani, V. (2018). The mediating effects of social entrepreneurial antecedents on the relationship between prior experience and social entrepreneurial intent. Journal of Science and Technology Policy Management, 9(3), 329346. doi:10.1108/JSTPM-03-2018-0028

Latif, M., \& Ali, S. (2020). Managerial ties as determinant of social entrepreneurial intentions: Does gender make a difference? Journal of Public Affairs, Article e2183, 1-11. doi:10.1002/pa.2183

Leadbeater, C. (1997). The rise of the social entrepreneur. London, UK: Demos.

Lee, S. H., \& Wong, P. K. (2004). An exploratory study of technopreneurial intentions: A career anchor perspective. Journal of Business Venturing, 19(1), 7-28.

Lent, R. W., Ireland, G. W., Penn, L. T., Morris, T. R., \& Sappington, R. (2017). Sources of selfefficacy and outcome expectations for career exploration and decision-making: A test of the social cognitive model of career self-management. Journal of Vocational Behavior, 99, 107-117.

Light, P. C. (2011). The search for social entrepreneurship. Strategic Direction, 27(6). doi:10.1108/sd.2011.05627fae.001/full/html

Liu, H.-C., Liang, C., Chang, C.-C., Ip, C. Y., \& Liang, C.-T. (2020). Optimizing personality traits and entrepreneurial creativity to boost the precursors of social entrepreneurial intentions: Five studies in Taiwan. Journal of Social Service Research, 47(1), 1-23. doi:10.1080/01488376.2019.1708840

Lortie, J., Castrogiovanni, G. J., \& Cox, K. C. (2017). Gender, social salience, and social performance: How women pursue and perform in social ventures. Entrepreneurship And Regional Development, 29(1/2), 155-173. doi:10.1080/08985626.2016.1255433

Lukes, M., \& Stephan, U. (2012). Nonprofit leaders and for-profit entrepreneurs: Similar people with different motivation. Ceskoslovenska Psychologie, 56(1), 41-55. 
Lukman, S., Bao, P. X., Kweku-Lugu, B., Arkorful, V. E., Latif, A., Gadabu, A., ... Sadiq, M. A. (2020). Diasporan students social entrepreneurship intention: The moderating role of institutional support. Journal of Public Affairs, Article e2108, 1-12. doi:10.1002/pa.2108

Lüthje, C., \& Franke, N. (2003). The 'making' of an entrepreneur: Testing a model of entrepreneurial intent among engineering students at MIT. R\&D Management, 33(2), 135-147.

Mair, J., \& Martí, I. (2006). Social entrepreneurship research: A source of explanation, prediction, and delight. Journal of World Business, 41(1), 36-44. doi:10.1016/j.jwb.2005.09.002

Mair, J., \& Noboa, E. (2005). How intentions to create a social venture are formed: A case study. Barcelona, Spain: IESE Business School.

Mair, J., \& Noboa, E. (2006). Social entrepreneurship: How intentions to create a social venture are formed. In Social entrepreneurship (pp. 121-135). London, UK: Palgrave Macmillan.

McCrae, R. R., \& Costa, P. T. (1987). Validation of the five-factor model of personality across instruments and observers. Journal of Personality and Social Psychology, 52(1), 81-90.

McMullen, J. S., \& Bergman, B. J. (2017). Social entrepreneurship and the development paradox of prosocial motivation: A cautionary tale. Strategic Entrepreneurship Journal, 11(3), 243270. doi:10.1002/sej.1263

Miller, T. (2012). Venturing for others with heart and head: How compassion encourages social entrepreneurship. Academy of Management Review, 37(4), 616-640. doi:10.5465/amr.2010.0456

Nga, J. K. H., \& Shamuganathan, G. (2010). The influence of personality traits and demographic factors on social entrepreneurship start up intentions. Journal of Business Ethics, 95(2), 259282. doi:10.1007/s10551-009-0358-8

Notais, A., \& Tixier, J. (2017). Girlz'n the hood: Discovering the determinants of social entrepreneurial intention of women in deprived urban areas. International Journal of Entrepreneurship and Small Business, 31(3), 382-398. doi:10.1504/IJESB.2017.084849

Pham, L. X., \& Phan, L. T. (2020). A conceptual model of social entrepreneurial intention based on three dimensions of social capital. International Journal of Entrepreneurship and Small Business, 4l(1), 115-128.

Phan, L. T. (2018). The relationship between perceived access to finance and social entrepreneurship intentions among university students in Vietnam. Journal of Asian Finance, Economics and Business, 5(1), 63-72. doi:10.13106/jafeb.2018.vol5.no1.63

Phan, L. T. (2020). The influence of personality traits on social entrepreneurial intention among owners of civil society organisations in Vietnam. International Journal of Entrepreneurship and Small Business, 40(3), 291-308.

Penner, L. A., Dovidio, J. F., Piliavin, J. A., \& Schroeder, D. A. (2005). Prosocial behavior: Multilevel perspectives. Annual Review of Psychology, 56, 365-392.

Podsakoff, P. M., MacKenzie, S. B., Bachrach, D. G., \& Podsakoff, N. P. (2005). The influence of management journals in the 1980s and 1990s. Strategic Management Journal, 26(5), 473-488.

Politis, K., Ketikidis, P., Diamantidis, A. D., \& Lazuras, L. (2016). An investigation of social entrepreneurial intentions formation among South-East European postgraduate students. Journal of Small Business and Enterprise Development, 23(4), 1120-1141. doi:10.1108/JSBED-03-2016-0047 
Poon, D. (2011). The emergence and development of social enterprise sectors. Social Impact Research Experience (SIRE), 1, 1-60.

Preethi, C., \& Priyadarshini, R. G. (2018). The intention towards social entrepreneurship among students and its link with Big 5 model. IOP Conference Series: Materials Science and Engineering, 390(1), Article 012057. doi:10.1088/1757-899X/390/1/012057

Prieto, L. C. (2011). The influence of proactive personality on social entrepreneurial intentions among African-American and hispanic undergraduate students: The moderating role of hope. Academy of Entrepreneurship Journal, 17(2), 77-96.

Radin, R. (2017). Social entrepreneurial intention among students of different status and university category. International Journal of Economic Research, 14(15), 377-394.

Rambe, P. (2019). Explaining social entrepreneurial intentions among college students in Zimbabwe. Journal of Social Entrepreneurship, 10(2019), 1-22. doi:10.1080/19420676.2019.1683878

Rivera, R. (2018). Predicting attitudes and behavioural intentions towards social entrepreneurship: The role of servant leadership in young people / Predicción de las actitudes y las intenciones conductuales hacia el emprendimiento social: el papel del liderazgo de servicio. Revista de Psicologia Social, 33(3), 650-681. doi:10.1080/02134748.2018.1482057

Rowley, J., \& Slack, F. (2004). Conducting a literature review. Management Research News, 27(6), 31-39.

Santos, F. M. (2012). A positive theory of social entrepreneurship. Journal of Business Ethics, 111(3), 335-351. doi:10.1007/s10551-012-1413-4

Shahverdi, M., Ismail, K., \& Qureshi, M. I. (2018). The effect of perceived barriers on social entrepreneurship intention in Malaysian universities: The moderating role of education. Management Science Letters, 8(5), 341-352. doi:10.5267/j.ms1.2018.4.014

Shane, S. (2008). The illusions of entrepreneurship: The costly myths that entrepreneurs, investors, and policy makers live by. New Haven, CO: Yale University Press.

Shane, S., \& Venkataraman, S. (2000). The promise of entrepreneurship as a field of research. Academy of Management Review, 25(1), 217-226.

Shapero, A., \& Sokol, L. (1982). The social dimensions of entrepreneurship. Retrieved December 11, 2020, from SSRN website: https://ssrn.com/abstract=1497759

Shaw, E., \& Carter, S. (2007). Social entrepreneurship. Journal of Small Business and Enterprise, 14(3), 418-434. doi:10.1108/14626000710773529

Short, J. C., Moss, T. W., \& Lumpkin, G. T. (2009). Research in social entrepreneurship: Past contributions and future opportunities. Strategic Entrepreneurship Journal, 3(2), 161-194. doi:10.1002/sej.69

Shumate, M., Atouba, Y., Cooper, K. R., \& Pilny, A. (2014). Two paths diverged: Examining the antecedents to social entrepreneurship. Management Communication Quarterly, 28(3), 404421. doi:10.1177/0893318914538561

Singh, A. (2016). The process of social value creation. New Delhi, India: Springer India.

Smith, R., Bell, R., \& Watts, H. (2014). Personality trait differences between traditional and social entrepreneurs. Social Enterprise Journal, 10(3), 200-221. doi:10.1108/SEJ-08-2013-0033 
Souitaris, V., Zerbinati, S., \& Al-Laham, A. (2007). Do entrepreneurship programmes raise entrepreneurial intention of science and engineering students? The effect of learning, inspiration and resources. Journal of Business Venturing, 22(4), 566-591. doi:10.1016/j.jbusvent.2006.05.002

Stephan, U. (2017). The person in social entrepreneurship: A systematic review of research on the social entrepreneurial personality. In The Wiley handbook of entrepreneurship (pp. 205229). Chichester, UK: John Wiley.

Sutter, C., Bruton, G. D., \& Chen, J. (2019). Entrepreneurship as a solution to extreme poverty: A review and future research directions. Journal of Business Venturing, 34(1), 197-214.

Tan, W.-L., \& Yoo, S.-J. (2015). Social entrepreneurship intentions of nonprofit organizations. Journal of Social Entrepreneurship, 6(1), 103-125. doi:10.1080/19420676.2014.954260

Tiwari, P., Bhat, A. K., \& Tikoria, J. (2017a). An empirical analysis of the factors affecting social entrepreneurial intentions. Journal of Global Entrepreneurship Research, 7(1), 1-25.

Tiwari, P., Bhat, A. K., \& Tikoria, J. (2017b). The role of emotional intelligence and self-efficacy on social entrepreneurial attitudes and social entrepreneurial intentions. Journal of Social Entrepreneurship, 8(2), 165-185.

Tiwari, P., Bhat, A. K., \& Tikoria, J. (2017c). Predictors of social entrepreneurial intention: An empirical study. South Asian Journal of Business Studies, 6(1), 53-79. doi:10.1108/SAJBS04-2016-0032

Tran, A. T. P., \& Von Korflesch, H. (2016). A conceptual model of social entrepreneurial intention based on the social cognitive career theory. Asia Pacific Journal of Innovation and Entrepreneurship, 10(1), 17-38. doi:10.1108/APJIE-12-2016-007

Tranfield, D., Denyer, D., \& Smart, P. (2003). Towards a methodology for developing evidenceinformed management knowledge by means of systematic review. British Journal of Management, 14(3), 207-222.

Unger, J. M., Rauch, A., Frese, M., \& Rosenbusch, N. (2011). Human capital and entrepreneurial success: A meta-analytical review. Journal of Business Venturing, 26(3), 341-358.

Urban, B. (2008). Social entrepreneurship in South Africa. International Journal of Entrepreneurial Behavior \& Research, 14(5), 346-364. doi:10.1108/13552550810897696

Urban, B., \& Kujinga, L. (2017a). Towards social change: South African university students as social entrepreneurs. South African Journal of Higher Education, 31(1), 243-259.

Urban, B., \& Kujinga, L. (2017b). The institutional environment and social entrepreneurship intentions. International Journal of Entrepreneurial Behavior \& Research, 23(4), 638-655. doi:10.1108/IJEBR-07-2016-0218

Urbano, D., Toledano, N., \& Soriano, D. R. (2010). Analyzing social entrepreneurship from an institutional perspective: Evidence from Spain. Journal of Social Entrepreneurship, 1(1), 54-69. doi:10.1080/19420670903442061

Waddock, S., \& Steckler, E. (2016). Visionaries and wayfinders: Deliberate and emergent pathways to vision in social entrepreneurship. Journal of Business Ethics, 133(4), 719-734. doi:10.1007/s10551-014-2451-X

Wallace, M., \& Wray, A. (2011). Critical reading and writing for postgraduates. Cornwall, UK: Sage Publications Limited. 
Wilson, F., Kickul, J., \& Marlino, D. (2007). Gender, entrepreneurial self-efficacy, and entrepreneurial career intentions: Implications for entrepreneurship education. Entrepreneurship Theory and Practice, 31(3), 387-406.

Wood, R., \& Bandura, A. (1989). Social cognitive theory of organizational management. Academy of Management Review, 14(3), 361-384.

Yang, R., Meyskens, M., Zheng, C., \& Hu, L. (2015). Social entrepreneurial intentions: China versus the USA - Is there a difference? International Journal of Entrepreneurship and Innovation, 16(4), 253-267. doi:10.5367/ijei.2015.0199

Zahra, S. A., \& Wright, M. (2011). Entrepreneurship's next act. Academy of Management Perspectives, 25(4), 67-83.

Zahra, S. A., Newey, L. R., \& Li, Y. (2014). On the frontiers: The implications of social entrepreneurship for international entrepreneurship. Entrepreneurship Theory and Practice, 38(1), 137-158. doi:10.1111/etap.12061

Zaremohzzabieh, Z., Ahrari, S., Krauss, S. E., Abu Samah, A., Meng, L. K., \& Ariffin, Z. (2019). Predicting social entrepreneurial intention: A meta-analytic path based on the theory of planned behavior. Journal of Business Research, 96, 264-276. doi:10.1016/j.jbusres.2018.11.030 